\title{
Hydrocarbon generation kinetics and physical properties of salinized lacustrine source rocks in the Upper Cretaceous-Paleocene South Yellow Sea Basin, offshore eastern China
}

\author{
PENG SU, SHOUZHI HU, YU SONG, CHUAN-BO SHEN \\ AND SHUIFU LI
}

Key Laboratory of Tectonics and Petroleum Resources (China University of Geosciences), Ministry of Education, Wuhan 430074, China

Presenting Author: 605799871@qq.com

Salinized lacustrine source rock, compared with source rocks from freshwater lacustrine basin and marine basin, has characteristics in enrichment of organic matter and evolution of hydrocarbon generation. In order to indicate the hydrocarbon generation kinetics of salinized lacustrine source rocks and predict the petroleum physical properties of generated fluids, salinized lacustrine source rocks from the Upper Cretaceous Taizhou Formation and Paleocene Funing Formation were collected for analysis. Here the analytical program included Rock-Eval pyrolysis, pyrolysis gas chromatography (Py-GC), source rock analyzer (SRA), and microscale sealed vessel (MSSV) pyrolysis analyses. Phase kinetic modeling was also employed on the basis of these data sets. The source rocks have high petroleum potential(HI $=422.45,435 \mathrm{mg} / \mathrm{g}$ TOC) and belong to an organofacies generating Paraffinic-NaphthenicAromatic low wax oil. Bulk petroleum generation can be respectively described by frequency factor $\mathrm{A}=9.66 \times 10^{12}$, $4.61 \times 10^{12}$ and dominant activation energy at $51,50 \mathrm{kcal} / \mathrm{mol}$. Onset (transformation ratio $\mathrm{TR}=10 \%$ ) and end ( $\mathrm{TR}=90 \%$ ) of bulk hydrocarbon generation were calculated respectively for an assumed average geological heating rate of $3.0^{\circ} \mathrm{C} / \mathrm{Ma}$, and oil windows $\left(128-155^{\circ} \mathrm{C}, 98-146^{\circ} \mathrm{C}\right)$ can be revealed. Compositional kinetic modeling predicts that the generated gas fraction mainly consists of $\mathrm{C}_{1}, \mathrm{C}_{2}$, and $\mathrm{C}_{3}$, while the liquid phase is predominated by compound groups of $\mathrm{C}_{7-15}$ and $\mathrm{C}_{16-25}$. Furthermore, physical properties of two suits of source rocks are described. The gas/oil ratio(GOR), saturation pressure $\left(\mathrm{P}_{\mathrm{sat}}\right)$ and formation volume factor $\left(\mathrm{B}_{\mathrm{o}}\right)$ vary in different maturation process(TRs). Black oil was almost generated in whole evolution stage of Funing and Taizhou mudstone. In addition, we using the pressure-temperature $(\mathrm{P}-\mathrm{T})$ envelope defined from these experiments, only a single liquid phase (black oil) is predicted at different TRs (10-90\%), What's more, in the process of the above analysis, we also made a comparison with marine and terrestrial source rocks. This paper provides the one case study with respect to kinetics description of salinized lacustrine source rocks. For another thing, the research also promote an acceleration of the progress in SYSB's petroleum exploration. 